Стадніченко О. О. кандидат філологічних наук, доцент Запорізького національного університету

\title{
РЕЦЕПЦІЯ ДУХОВНОСТІ ТА АНТИДУХОВНОСТІ В ЕПОХУ ШІСТДЕСЯТНИЦТВА В МЕМУАРАХ «ЯК ПО СТРУНІ БЕЗОДНЮ...» ЛЕОНІДА КОРЕНЕВИЧА
}

Мемуари Л. Кореневича “Як по струні безодню...” є оригінальним твором не тільки про кожного особисто, а який представив покоління шістдесятників в особах, з аналізом їхніх духовних, ідеологічних і світоглядних засад, чітко відтворивши долю тих, хто пов'язав іï з українськими національним відродженням 1960-х років. Виписаний у спогадах образ автора вражає гармонійністю, сконденсованістю $і$ изілісністю $i$ ніби підіймається над процесами, перебіг яких представлено в спогадах.

Ключові слова: мемуаристика, спогади, аспект, щоденники, листи.

Мемуары Л. Кореневича “Как по струне бездну." является оригинальным произведением не только о каждом лично, а которое представило поколение шестидесятникив в лицах, с анализом их духовных, идеологических и мировоззренческих принципов, четко воспроизведши судьбу тех, кто связал ее с украинскими национальным возрождением 1960-х годов. Выписанный в воспоминаниях образ автора поражает гармоничностью

Ключевые слова: мемуаристка, воспоминания, аспект, дневники, письма.

The memoirs "As at the edge of the abyss" by Leonid Korenevych are original work not only about their lives but the memoirs that present generation of 60-ies as characters who recreated the fate of those ones associated with Ukrainian national revival of the 1960 s and analysis of their ideology.

Author's image created in recollection impresses by harmony and integrity rising above the events that take place in the memoirs.

Key words: memoirs, remembrances, aspect, diaries, letters. 
Наприкінці XX століття в українському суспільстві відбулося багато змін, які дозволили йому стати відвертішим і відкритішим. Упала залізна завіса Україна стала доступною для своєї діаспори, тобто до материкової української нарешті доєдналася та, яка творилася далеко за іï межами і певною мірою відрізнялася від тієї, що була в щільних рамках соцреалізму. Письменники, політичні діячі, представники різних творчих кіл більш сміливо виливають свої спогади на папір, довіряючи йому те, за що при попередній владі можна було поплатитися власною свободою. Поряд з художньою літературою, в основі якої художнє моделювання дійсності, стає література документа й факту.

Літературознавець О. Галич вважає, що «Документалістика, особливо

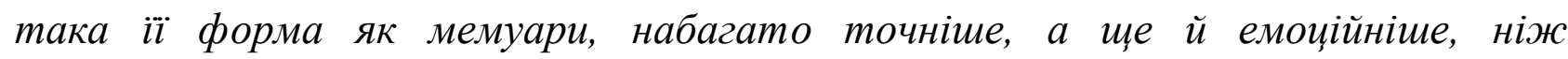
донедавна вузівські та шкільні підручники, відтворює далеке й більш віддалене минуле, провідні історичні тенденції, дає оцінки реальним політичним діячам, письменникам, акторам у різні періоди (відносно спокійні чи драматичні, а той трагічні) нашої історії. Спогади часом називають третьою історією, маючи на увазі, щуо перша історія - цее справжній суспільний процес, щуо мав місце в минулому; друга - це його бачення в офіųіозі; а третя - неупереджений погляд мемуариста чи автора біографічної оповіді» [Галич 2001:5].

Нині актуальним $є$ осмислення ролі i значущості мемуаристики у формуванні уявлення сучасників про історичне тло певної епохи, зокрема доби шістдесятництва, а також про суб’єктивно-особистісний зміст мемуарної літератури.

Про культурно-естетичний феномен шістдесятництва, витоки, суть та наслідки цього літературно-мистецького руху написано чимало досліджень i розвідок, як літературознавчого, мистецтвознавчого, культурологічного, так i філософського та суспільно-політичного характеру. Проаналізовано, як цей рух відбився на подальшому розвитку літератури і мистецтва, що спричинило його згортання, створено монографічні праці, присвячені творчості представників шістдесятництва. Здавалося б, певною мірою крапки розставлені. Але останнім часом серед помітного пожвавлення художньої документалістики в українській 
літературі з’явилося низка мемуарів (спогадів, щоденників, листів, мемуарних нотаток, колективних збірників спогадів, які часто супроводжуються різного роду документами) власне шістдесятників, які «без ретуші i гриму» розкривають ті процеси, що відбувалися всередині «шістдесятництва», їхні стосунки з тодішньою владою, керівництвом творчих спілок, творчою елітою старшого покоління, яке, переживши репресії, голодомори, різного роду політичні утиски, пристосувалося до тісних рамок соцреалізму. Тобто ці мемуари $\epsilon$ автопортретом кожного особисто i цілої доби шістдесятництва загалом.

Серед тих, чиї мемуари дозволяють більш детально розглянути цей складний літературно-мистецький феномен, розвінчують ідеологічні міфи і яскраво демонструють сучасникам, як непросто було в тих умовах сповідувати національні цінності, представники покоління шістдесятників: В. Дрозд, І. Дзюба, І. Жиленко, Л. Кореневич, М. Коцюбинська, Л. Танюк та ін.

Автор мемуарів «Як по струні безодню...» - один із шістдесятників Леонід Кореневич, який був ініціатором створення 1956 р. у Москві земляцтва українських студентів, учасником відкриття пам'ятника Т. Шевченку на Косівщині, за що був звільнений з посади кореспондента "Робітничої газети” за притуплення політичної пильності та звинувачений у націоналізмі, вважав що «иістдесятництво - иче явище, стоїть сьогодні перед судом історії, як $і$ всі ті, хто так чи інак причетні до нього. Розглядати шістдесятництво можна й треба тільки з розумінням тих історичних процесів, які його породили, й особистої - із знаком плюс чи мінус - причетності до нього. Як на мене, $і$ досі ніхто не заперечував, шістдесятництво виникло на гребені хрущуовської відлиги й сформувалося під впливом нищівной критики літературного мафіозноолігархічного соцреалізму спершу в російській, а трохи пізніше $і$ в украӥнській літературі» [Кореневич 2004:42].

У мемуарах самих представників руху шістдесятництва зустрічаємо досить різні оцінки того, що тоді відбувалося, що дає підстави говорити про їхній особистісно-суб’єктивний характер. 
Як згадують шістдесятники, проблеми оновлення літератури і мистецтва постійно ставали в центрі уваги у творчих та наукових колах, де відбувалися досить гарячі дискусії, часто навіть не досить толерантно стосовно один одного. Тепер, з плином часу та зміною стереотипів і переоцінкою цінностей, зі спогадів сучасників випливають цікаві деталі, що стосуються реакції класиків літератури і політичних діячів.

У книзі «Як по струні безодню...» Л. Кореневич досить докладно характеризує цю добу, зокрема звертаючи увагу на те, як це явище починалося: «На периих порах кожен входив у літературу, в мистецтво самостійно. I. Драч, М. Вінграновський, В. Симоненко, В. Шевчук, С. Гуцало, Ю. Щербак, I. Дзюба, I. Світличний, В. Стус - у кожного була своя ідея і свій шлях. Та всіх їх об’єднувало, як каже І. Жиленко, єдине дихання $i$ єдиний порив. Бо шістдесяті роки ставили перед кожним, $i$ перед усіма разом, одні й ті ж питання, хоча відповіді на них кожен иукав своєї. Ті, щзо думали інакше, ніж працівники номенклатурного мистецтва, становили загрозу для літературного олімпу. [...] Та чим більще повчали, потовчуючи молодих, тим більше вони згуртовувались, иукали і знаходили один одного» [Кореневич 2004:43].

У спогадах Л. Кореневича характерною рисою $є$ якась гранична відвертість, на межі навіть образи на деякі тодішні обставини і людей, які відіграли вирішальну роль у долі шістдесятників, якась нереалізованість чи втрачена можливість, бажання не тільки донести своє суб'єктивно-особистісне бачення, але й наголосити на окремих деталях, які засіли глибоко в його душі. Він наполягає на тому, що шістдесятництво як явище потребує відповідального вивчення й дослідження. Автор вважає, що не можна розглядати всіх під одним кутом зору, адже кожен ішов до цього своїм шляхом. Л. Кореневич недвозначно стверджує: «Я нікого не хочу сьогодні ні засуджувати, ні плямувати, але й від минулого свого не відрікаюся. [...]. Та як часто в оцінках минулого дехто сьогодні намагається стати при хвіртці історії й першим відкривати ї̈, приміряючи на себе мантію короля, з-під якої входили в історію мушкетери-иістдесятники» [Кореневич 2004:43]. 
Про чинники формування нового мислення у творчої молоді, Л. Кореневич зазначає, що шістдесятництво вийшло 3 20-х років, і естафету вони підхопили від тих, хто не зламався в сталінських концтаборах: Б. Антоненка-Давидовича, Г. Кочура, В. Гжицького, В. Мисика, дружин репресованих письменників, що загинули в катівнях. У спогадах шістдесятників неодноразово наголошується, що першим паростком шістдесятництва і зв'язковим між поколіннями був I. Дзюба 3 його книгою «Звичайна людина чи міщанин?» (1959), який тоді був заввідділу критики журналу “Вітчизна” і саме він пропускав до друку найвагоміші статті М. Коцюбинської, С. Сверстюка, І. Світличного, вірші В. Голобородька, I. Драча, прозу В. Шевчука та $Є$ Гуцала, за що був підданий нищівній критиці 3 боку представників літературного олімпу. Це підтверджується і спогадами I. Жиленко, яка писала, що в І. Дзюбу «без перебільшення був закоханий весь інтелігентський Київ, [..] а кожен його вихід на трибуну - поєдинок». І. Жиленко, яку цитує Л. Кореневич, небезпідставно зауважувала, що «Іван розкривав лицемірну “кухню” тодішньої літературної критики. Він цчитував, зіставляв, ловив поважних письменників на брехні, пересмикуванні, доносництві й хамелеонстві. Він знищував таких дощуенту при ц̧ьому не знав страху, не мав жодного поняття про стратегію й хитру дипломатію» [цит. за Кореневич 2004:44]. Вона називала I. Дзюбу «символом часу», «володарем дум $i$ змістовником правди», якого страшенно ненавиділа літературна й політична верхівка. Але, як зауважував Л. Кореневич, «ніхто не наважувався першим скерувати изькування в потрібне русло» [Кореневич 2004:45].

Ясна річ, що мемуари, написані з плином часу, будуть певною мірою осучаснені, позначені суб’ єктивністю, але в той же час позначені патріотичною риторикою, крізь яку пробиваються свідчення очевидця та «речові докази». «Історизм, документальна вірогідність, правда моменту, щзо їх можна перевірити незаперечним фактажем, історичним розвитком подій, сьогоднішньою реальністю. Маємо своєрідне взаємовідображення, систему 
складних дзеркал. У зіткненні кількох ситуативних “правд” народжується Правда, перевірена часом, живий Образ минулого» [Коцюбинська 2008:57].

У мемуарах більше ніж у художній літературі зустрічаємо людинознавчих категорій, психологічних мотивацій поведінки людини, моральноекзистенційної проблематики, сповідальності, портретів і автопортретів. Часто автор спогадів переживає гризоти сумління, пов'язані з тим, чи має він право на оприлюднення тих чи інших фактів, які він вважає важливими для створення не тільки автопортрету, а й відтворення правдивого (але в той же час суб'єктивного) образу доби. Особливо, коли це стосується відомих людей, про яких у суспільній свідомості вже складений певний, найчастіше позитивний, образ.

У спогаді-есе «Град 3 крапель смутку» Л. Кореневич будує «історичну хронологію» подій, пов'язаних з критикою шістдесятників, хоча вони й не були утаємниченими, варто було звернутися до тодішніх газет, про які зараз не всім хотілося б згадувати. Він нагадує, що йтиметься про Павла Загребельного, якого багато хто і зараз вважає «батьком» шістдесятників. I справді, зазначає Л. Кореневич, П. Загребельний як редактор «Літературної газети» «пригортав під своє крило молодих, надаючи їм иілі сторінки, терпляче зносячи погрози й партійні напучування керівних партійних $i$ літературних мужів, усіх ідеологічних філістимлян з ЦК, які вимагали від П. Загребельного дати молодих у руки їхні〉 [Кореневич 2004:45].

Автор спогадів взяв на себе сміливість припустити, що коли П. Загребельний побачив, що політична ситуація навколо шістдесятників загострилася, вирішив за краще не ризикувати з власть імущими, а першим нанести удар по тих, до кого досі був прихильним. «І видавив із себе оті “Три каплі смутку”». Він либонь і не сподівався, що з тих крапель на голови багатьох молодих, а найперше на голову I. Дзюби, впаде справжній град. Бо влада тільки й ждала влучного приводу, щоб скерувати на Дзюбу, а через нього й на всю літературну молодь, всю міць своєї несамовитої люті до «відщепенців», «відступників», «продажних спекулянтів» і т.д. і т.п. Система психічних засобів 
почала працювати, намагаючись за всяку ціну скомпрометувати Івана Дзюбу та його «спільників». «Відлига» закінчувалася, «починалися ожеледь, налипання мокрого снігу» [Кореневич 2004:46].

Л. Кореневич відверто намагається з’ясувати ту ситуацію, не розуміючи, як П. Загребельний дозволив собі так брутально поставитися до молодих критиків, які надрукували свої статті у «Вітчизні». Відчувається, що авторові спогадів приємніше було б згадувати щось цікаве, що привернуло б увагу читача, а не коментувати статтю, яку класик української літератури навіть не включав до жодного списку, бо не хотів про неї згадувати. Але, намагаючись не грішити істиною, він дошукується правди, що саме спонукало П. Загребельного розв’язати війну з молодими.

П. Загребельний, зокрема, писав: «Впродовж останніх трьох місяців я одержав чергові три номери журналу «Вітчизна». В кожному з циих номерів я знайшов по одній оглядовій критичні статті. Кожна стаття - мов крапля смутку» [Кореневич 2004:50]. Як виявляється, першою «краплею смутку» П. Загребельний назвав статтю І. Світличного «Людина приїздить на село», присвячену оглядові “сільських романів”. Другою - «Критичні розважання молодого літератора Л. Кореневича на тему сучасного нарису. Та ще які!», у якій аналізувався), на думку П. Загребельного, «сумний універсалізм у долі сучасного нарису» [Кореневич 2004:54]. I, нарешті, - третя крапля смутку стаття О. Ставицького «Як у житті...», присвячена критичному оглядові української історичної прози.

Стаття П. Загребельного дуже докладно піддає брутальній критиці праці молодих літературознавців, які висловили зауваження на адресу імен та творів, до яких ні в якому разі не можна підходити з критичними мірками. «Якщзо таку критичну, з дозволу сказати, практику розповсюдити на все мистецтво, то тоді фрлеиту ми вважатимемо просто собі шматочком деревини, а стрункий квартет Чайковського буде не щзо інше, як тертя кінського хвоста об баранячу кимку. [...] Три краплі смутку - цฺе щฺе не сльози. Не стану побиватися й плакати з приводу появи изих статей. Мене дивує похмурий ентузіазм редакції 
журналу “Вітчизна”, з яким вона “итурмує” нашу літературу» - підсумовує П. Загребельний [Кореневич 2004:59].

Автор спогадів згадує, що публічний виступ П. Загребельного зробив цю трійцю знаменитими і дозволив познайомитися 3 багатьма цікавими людьми 3 когорти шістдесятників, але в той же час i пережити момент розпачу i розгублення. Тим більше, що після появи цієї статті почалися офіційні переслідування шістдесятників. Хоча, на думку сучасників того руху, самі назви “шістдесятництво” та “шістдесятники” з’явилися значно пізніше і не зовсім коректно відбивають хронологічні рамки, на які припадає розвиток цього літературно-мистецького явища як в Україні, так і в інших республіках колишнього Союзу.

Л. Кореневич продовжує, що питання, порушені П. Загребельним, стали предметом розгляду на засіданні секції критики Спілки письменників України. Відновлюючи історичну справедливість, автор констатує, що все-таки більшість письменників підтримали молодих критиків. Знакову роль у цій дискусії відіграв літературознавець Л. Новиченко, який практично відкинув усі звинувачення щодо відділу критики журналу «Вітчизна» на чолі 3 І. Дзюбою, проти якого i був спрямований увесь цей шквал критики. У спогадах наводяться слова Л. Новиченка: «Якщзо підсумувати все, про щзо ми говорили, проти ілюстративності, тобто проти такого творчого методу, коли письменник не виявляє себе як мисляча особистість, а тільки намагається ілюструвати життя квітчастими метафорами. Вони виступають проти художньої безликості, проти итампів, інертності. Вони не завжди володіють аргументащією, але ц̧е наступ проти тих речей, які зараз відживають в нашій літературі» [Кореневич 2004:61].

Спогад-есе Л. Кореневича «Град 3 крапель смутку» 3 великим нашаруванням особистісного сприйняття відтворює досить суперечливу i складну картину доби шістдесятництва. Особливо докладно описує він постать Л. Новиченка, який не міг поступитися принципами творчості і підтримати офіційну лінію щодо шістдесятництва. Натомість автор подає його портрет як 
професіонала i людини високого морального обов'язку, наголошуючи при цьому, що Л. Новиченко передбачливо зауважив у «Літературній газеті»: «Не без побоювання думаєщ, щзо коли після такого висновку в автора статті «Три краплі смутку» знайдуться ентузіасти-послідовники, то може справді з'явитися певний смуток $і$ для украӥнської критики, $i$ для украӥнської літератури в цүілому - бо иุі поняття, в суті своїй, єдині» [Кореневич 2004:63].

Л. Кореневич не без образи продовжує з’ясовувати причини, які спонукали П. Загребельного так виступити, що, по-суті, стало поштовхом до різних оргвисновків, які багатьом 3 тих, хто під них потрапив, навіть зламали долю: хтось був звільнений з роботи, зокрема І. Дзюба, Д. Копиця та ін., хтось просто замовк, хтось зламався, злякавшись того галасу, що зчинився. “Нас менш цікавить сьогодні: 3 власної волі чи на вимогу відповідальної часової хвилі виступив П. А. Загребельний. Але залишається фактом, що його “Три краплі смутку” об’єктивно набрали дивного характеру: після них, як пізніше писав I. Дзюба, одні за одними у Києві відбулися наради, пленуми, конференції, на яких нещадно таврували «формалістів-шістдесятників», перекривали талановитій людині шлях до читача. [...] Політична відлига, розпочата М. С. Хрущовим, змінювалася ним же ініційованими «заморозками». «Три краплі смутку» 3’явилися вчасно: стукнуло, грюкнуло... і відгукнулося» [Кореневич 2004:65]. Автор спогадів висловлює припущення, що «Три краплі смутку», можливо, випадково виявилися на вістрі подій. Але, на його думку, саме вони стали «початковим етапом бурі - заклятої й рімучої боротьби 3 тими, хто виступив проти закам'янілих масок» [Кореневич 2004:65].

Аналіз, хоча $б$ поверховий, з точки зору змісту, а не форми, спогадів, мемуарних нотаток, щоденників, листів шістдесятників дозволяє зазначити, що всі різняться за ступенем вияву суб'єктивності-об'єктивності, присутності (більшої чи меншої) самого автора, емоційністю чи офіційністю викладу, деталізацією, наявністю портретних характеристик, передачею монологів чи діалогів і т.д. Це залежить від особистості мемуариста, його здатності реалістично, і водночас колоритно і художньо передати свої спогади. Часто це 
не вдається, оскільки занадто серйозно чи навіть офіційно вони подаються, особливо, коли долучаються судові справи, протоколи допитів, різного роду документи, які додають мемуарам документальності. Характер оповіді часом залежить від статі оповідача: як правило, жіночі мемуари більш емоційні.

3 висоти літ, що відділяють нас від тих подій, а також суттєвих змін, які відбулися в свідомості людей і в ідеології, здається дивним те, що нові віяння фактично в літературі та мистецтві спричинили масові політичні переслідування, коли мистецтво розглядалося не в естетичній, а в ідеологічній площині. Таке могло бути тільки в умовах так званого соцреалістичного мистецтва, коли все регламентувалося партійними приписами. Мемуари людей, які були у вирі цих подій, відкривають читачеві реалії «без ретуші і гриму». Ясна річ, що автори мемуарів не можуть утриматися від емоційно-оціночних суджень на адресу тих чи інших персонажів їхніх спогадів - занадто роз'ятреними є їхні рани до цього часу. Багатьох з них уже немає серед живих. А живі, маючи величезний досвід боротьби 3 системою, - стали на чолі національно-політичних рухів, які здобули Україні незалежність.

Мемуари Леоніда Кореневича “Як по струні безодню” є оригінальним твором не тільки про кожного особисто, а якиий представив покоління шістдесятників в особах, 3 аналізом їхніх ідеологічних і світоглядних засад, чітко відтворивши долю тих, хто пов’язав іiі з українськими національним відродженням 1960-х років. Виписаний у спогадах образ-портрет автора вражає гармонійністю, сконденсованістю i цілісністю i ніби підіймається над процесами, перебіг яких представлено в спогадах.

\section{БІБЛІОГРАФІЯ}

Галич 2001 - Галич О. А. Українська документалістика на зламі тисячоліть: специфіка, ґенеза, перспективи / Галич О. А. - Луганськ : Альмаматер, 2001. - 246 c.

Коцюбинська 2008 - Коцюбинська М. Х. Історія, оркестрована на людські голоси. Екзистенційне значення художньої документалістики для сучасної 
літератури / Коцюбинська М. Х. - Київ : Видавничий дім «Києво-Могилянська академія». $-2008 .-70$ с.

Кореневич 2004 - Кореневич Л. Як по струні безодню...Кілька особистих сторінок до біографії шістдесятництв / Кореневич Л. - Київ : Смолоскип. 2004. -260 c. 